\title{
DOES IMMIGRATION INCREASE CONCERNS ABOUT THE PROVISION OF PUBLIC SERVICES? EVIDENCE FROM COLOMBIA
}

¿Aumenta la inmigración las preocupaciones sobre la prestación de servicios públicos? Evidencia de Colombia

A imigração aumenta a preocupação com a prestação de serviços públicos? Evidências da Colômbia

\section{CATALINA VEGA-MENDEZ (1) cvegamen@purdue.edu ${ }^{1}$ GIANCARLO VISCONTI (10 gviscont@purdue.edu ${ }^{1}$}

\footnotetext{
1 Purdue University

Submission: 2020-09-21

Accepted: 2021-05-07

First View: 2021-05-31

Publication: 2021-05-31
}

\begin{abstract}
Keywords: Immigration; Public Services;

Health;

Education;

Colombia;

Venezuela

\section{Abstract}

Although South American countries have experienced unprecedented regional migration in the last decade, there is little research on the impact of these demographic changes on citizens' political preferences. Does exposure to immigration affect native residents' concerns about the provision of public services? To address this question, we use survey data from the AmericasBarometer in Colombia before and after the immigration wave generated by the 2015 political and economic crisis in Venezuela. We implement a differencein-differences design to estimate the effect of distance from border crossings between Colombia and Venezuela on respondents' concerns about the provision of healthcare and education after the large and rapid influx of immigrants. We find that, after 2015, respondets living closer to a border crossing are more likely to identify a lack of provision of health services, though not education, as
\end{abstract}




\begin{tabular}{|c|c|}
\hline & $\begin{array}{l}\text { one of their primary concerns. These results have relevant political implications } \\
\text { since previous research has shown that a fiscal burden on public services can } \\
\text { trigger anti-immigration attitudes in host communities. }\end{array}$ \\
\hline $\begin{array}{l}\text { Palabras clave: } \\
\text { inmigración; } \\
\text { servicios } \\
\text { públicos; salud; } \\
\text { educación; } \\
\text { Colombia; } \\
\text { Venezuela }\end{array}$ & $\begin{array}{l}\text { Resumen } \\
\text { Aunque los países de América del Sur han experimentado una migración regio- } \\
\text { nal sin precedentes en la última década, hay poca investigación sobre el impacto } \\
\text { de estos cambios demográficos en las preferencias políticas de los ciudadanos. } \\
\text { ¿La exposición a la inmigración afecta las preocupaciones sobre la prestación de } \\
\text { servicios públicos? Para abordar esta pregunta, utilizamos datos de encuestas } \\
\text { del Barómetro de las Américas en Colombia antes y después de la ola migra- } \\
\text { toria generada por la crisis política y económica de } 2015 \text { en Venezuela. Imple- } \\
\text { mentamos un diseño de diferencias en diferencias para estimar el efecto de la } \\
\text { distancia desde los cruces fronterizos entre Colombia y Venezuela sobre las } \\
\text { preocupaciones de los encuestados sobre la provisión de atención médica y } \\
\text { educación después de la gran y rápida afluencia de migrantes. Mostramos que, } \\
\text { después de } 2015 \text {, los encuestados que viven más cerca de un cruce fronterizo } \\
\text { tienen más probabilidades de identificar la falta de prestación de servicios de } \\
\text { salud pero no de educación como una de sus principales preocupaciones. Estos } \\
\text { resultados pueden tener implicaciones políticas relevantes, ya que investigacio- } \\
\text { nes anteriores han demostrado que una carga fiscal sobre los servicios públicos } \\
\text { puede desencadenar actitudes antiinmigrantes en las comunidades de acogida. }\end{array}$ \\
\hline $\begin{array}{l}\text { Palavras-chave: } \\
\text { imigração; } \\
\text { serviços } \\
\text { públicos; saúde; } \\
\text { educação; } \\
\text { Colômbia; } \\
\text { Venezuela }\end{array}$ & $\begin{array}{l}\text { Resumo } \\
\text { Embora os países da América do Sul tenham experimentado uma migração re- } \\
\text { gional sem precedentes na última década, há poucas pesquisas sobre o impacto } \\
\text { dessas mudanças demográficas em relação as preferências políticas dos cida- } \\
\text { dãos. A exposição à imigração afeta as preocupações dos residentes nativos em } \\
\text { relação a prestação de serviços públicos? Para responder essa questão, usamos } \\
\text { os dados da pesquisa do AmericasBarometer na Colômbia antes e depois da } \\
\text { onda de imigração gerada pela crise política e econômica de } 2015 \text { na Venezue- } \\
\text { la. Além disso, também implementamos um projeto de diferença em diferenças } \\
\text { para estimar o efeito da distância das travessias de fronteira entre a Colômbia } \\
\text { e a Venezuela em relação as preocupações dos entrevistados acerca do for- } \\
\text { necimento de saúde e educação após o grande e rápido influxo de imigrantes. } \\
\text { Evidenciamos que, após } 2015 \text {, os entrevistados que moram perto de uma pas- } \\
\text { sagem de fronteira têm maior probabilidade de identificar a falta de prestação } \\
\text { de serviços de saúde, mas não de educação, sendo essa uma de suas principais } \\
\text { preocupações. Esses resultados podem ter implicaçães políticas relevantes, } \\
\text { uma vez que pesquisas anteriores mostraram que uma carga fiscal sobre os } \\
\text { serviços públicos pode desencadear atitudes anti-imigração nas comunidades } \\
\text { anfitriãs. }\end{array}$ \\
\hline
\end{tabular}


VEGA-MENDEZ AND VISCONTI

DOES IMMIGRATION INCREASE CONCERNS ABOUT THE PROVISION OF PUBLIC SERVICES?

EVIDENCE FROM COLOMBIA

\section{INTRODUCTION ${ }^{1}$}

While South American countries have experienced unprecedented migration from Venezuela in the last decade-more than 4 million by the end of 2019-, there is little evidence about how exposure to immigration affects citizens' political preferences in the region. A large part of the research on migration only focuses on how demographic changes affect people's attitudes and preferences in developed countries (Dancygier and Laitin, 2014; Hainmueller and Hopkins, 2014), which produces significant geographic biases in our knowledge of the phenomenon (Alrababa'h et al., 2021).

In developing countries, a large part of the population depends on the provision of public services by the state. In this context, demographic transformations might increase anxiety and concerns about competition for public goods such as healthcare and education. ${ }^{2}$ In this paper, we use evidence from Colombia to study whether exposure to a large influx of economic migrants and refugees increases residents' concerns about the provision of public services. Answering this question becomes especially relevant because of previous research showing how a fiscal burden on public services can trigger anti-immigration attitudes in host communities (Facchini and Mayda, 2009). Additionally, understanding how the local population reacts to demographic changes is crucial for improving the integration of immigrant communities and reducing the discrimination and stereotyping of foreigners. Pinpointing the issues that locals identify as problems after large immigration waves could allow governments to concentrate their efforts on addressing those concerns, and as a result, reduce the saliency of immigration-related issues.

Using evidence from Colombia, we examine how exposure to a massive and rapid influx of immigrants from Venezuela has affected host citizens' concerns about the provision of public goods. Since 2014, more than 1.4 million people have entered Colombia from Venezuela (UNCHR and OIM 2019). During this time, Colombia has also experienced significant economic and political transformations, with the country taking significant steps towards ending its internal

1. We thank Cherie Maestas, Eric Waltenburg, and Matt Ellis for useful comments and suggestions. We thank the Latin American Public Opinion Project (LAPOP) and its major supporters (the United States Agency for International Development, the Inter-American Development Bank, and Vanderbilt University) for making the data available. All errors are our own.

2. Traditional economic approaches define public goods as resources that are both non-excludable and non-rivalrous, which means that people cannot be excluded from using them and their use by one individual does not affect the availability to others (Samuelson, 1954). Accordingly, education or health might not be considered public goods for some authors because one person's consumption might diminish the quality of the good for others. In this paper we follow a more nuanced definition by understanding public goods as resources that benefit not only the individuals but also the entire society by generating a wide variety of social benefits (Tilak, 2008). Therefore, we use public goods and public services interchangeably. 
conflict between the FARC guerrilla group and the government. Despite this, post-conflict Colombia still faces several challenges. The multidimensional costs of more than 50 years of civil conflict left severe territorial development gaps, high levels of inequality, and a concentration of means of production such as land. Some areas of the country face significant disparities in their level of economic development and access to basic services (World Bank, 2018).

To understand how people update their concerns about the provision of public goods after demographic changes, we use four rounds of the AmericasBarometer survey in Colombia: two from before the 2015 massive influx of Venezuelan economic migrants and refugees $(2013,2014)$ and two after $(2016,2018)$. Survey respondents are georeferenced by municipality to estimate their distance from border crossings between Colombia and Venezuela. Our outcome of interest is a binary indicator of whether the (lack of) provision of healthcare or education is the most important problem respondents perceive the country is facing. We construct an exposure to immigration indicator using the distance from the respondent municipality of residence to the nearest border crossing from Venezuela, which works as a proxy of the level of exposure to immigration. We exclude the largest cities in Colombia-Barranquilla, Bogotá, Cali, and Medellin-because exposure to migration in those places should not be explained by distance to the border. We implement a difference-in-differences design (DID) to estimate the effect of distance from the nearest official border crossings with Venezuela after the 2015 immigration crisis. ${ }^{3}$

This paper seeks to make three significant contributions to the existing literature. First, while there has been empirical research on public attitudes towards migrants in the US and Western Europe, there is little research about the effects of large-scale migration in developing countries, where a large part of migration occurs (UNHCR, 2017). Second, most of the literature studying the economic variables that affect the formation of migration-related preferences focuses only on income and unemployment. However, gaining insights about the effects of large immigration waves in developing countries requires paying more attention to other concerns such as the provision of public goods. Third, since previous research

3. Venezuelans do not need a visa to enter Colombian territory. They can enter the country as tourists without any kind of restriction. As a result, we expect them to mainly use official border passes when crossing from Venezuela to Colombia. However, is important to acknowledge during the period of study there have been moments of restrictions of official border crossings. First, in 2015 the Venezuelan government decided to restrict the official border crossing for approximately 12 months. During this time, the Colombian government managed to negotiate a humanitarian corridor that allowed the crossing of students, people in need of healthcare, and other exceptional cases. On August 13, 2016, Venezuela officially reopened its border with Colombia. Additionally, on October 2, 2016, June 14, and March 11, 2018 the Colombian government closed its border due to the plebiscite and the presidential elections (first and second round), respectively (Colombia Migration, 2019). 
VEGA-MENDEZ AND VISCONTI

DOES IMMIGRATION INCREASE CONCERNS ABOUT THE PROVISION OF PUBLIC SERVICES?

EVIDENCE FROM COLOMBIA

has illustrated how worries about competition for public services can trigger hostility towards immigrants, having a better understanding of these concerns could allow governments to address them to facilitate the integration of migrants.

\section{PROVISION OF PUBLIC GOODS IN LATIN AMERICA}

As opposed to most Western societies, Latin American countries do not offer strong welfare programs to their citizens (Segura, 2007; Haggard and Kaufman, 2008; Noy and Voorend, 2016). In the absence of a wide repertoire of state-led policies aiming to achieve a minimum level of social protection for its people, the provision of basic goods and services such as education and healthcare is crucial for citizens, especially for the less privileged.

What explains the quality of provision of public goods in Latin America? Previous research has shown that contextual factors play a critical role in the distribution of social benefits and the provision of public services such as education and healthcare in the region. This literature has focused on social mobilization (Garay, 2010), electoral competition and attempts to expand electoral coalitions (Pribble, 2015; Garay, 2010), political alignment (Niedwiecki, 2016), the nature of political coalitions (Giraudy and Pribble, 2020), the actions of powerful veto players (Castiglioni, 2001), and the emergence of left-wing parties during the 2000s (Huber et al., 2008; Huber and Stevens, 2012).

In the case of Colombia, the state provides middle-range education and healthcare coverage and limited risk-coping programs (Pribble, 2011). The worst deficits in public services such as education and healthcare are concentrated in rural localities (ECLAC, 2016). Further, recent studies show that the decades of armed conflict have undermined municipalities' effectiveness in providing health and education services (Rodriguez, 2009). The provision of public goods and services is not only a matter of subnational factors but rather can also be affected by place-sensitivity (Otero-Bahamón, 2020). For example, well-designed policies that take local conditions into account, as opposed to one-size-fits-all policies, can improve the provision of public services and therefore enhance peoples' living conditions.

As a result, the contextual, fragile, and uneven provision of public and services in Latin America suggests that large demographic changes might factor into how people update their concerns and priorities about the provision of public goods and services. Better understanding how people react to these transformations is especially important in democratic contexts where we expect governments to be responsive to citizens and for citizens to hold governments accountable for their performance. But also, following Otero-Bahamón (2020), the state might have an opportunity to improve the provision of public goods and services if they follow 
VEGA-MENDEZ AND VISCONTI

DOES IMMIGRATION INCREASE CONCERNS ABOUT THE PROVISION OF PUBLIC SERVICES?

EVIDENCE FROM COLOMBIA

a place-sensitivity approach by taking into account the local context: in this case, the demographic changes associated with the arrival of large numbers of immigrants to border localities.

\section{IMMIGRATION AND ECONOMIC THREATS IN THE GLOBAL SOUTH}

Political economy approaches for public opinion towards migrants have argued that economic concerns about immigration are founded on fears about labor market competition and a fiscal burden on public services (Facchini and Mayda, 2009; Hainmueller and Hiscox ,2010). These two issues have dominated debates about immigration policy in the US (Borjas, 2001) and have been used to explain anti-immigrant attitudes in the UK (Simon et al., 1999).

The labor market competition model predicts that the supply of low-skilled labor will increase with the arrival of low-skilled immigrants, which will deteriorate both wages and employment levels (Scheve and Slaughter, 2001). Similarly, the fiscal burden on public services model predicts that low-skilled immigrants will be a net burden for the state, which can either react by raising taxes or decreasing public spending (Hanson, Scheve, and Slaughter 2007). There is evidence showing that low-income natives are more likely to oppose low-skilled immigration in places with greater fiscal exposure in terms of immigrant access to public services; ${ }^{4}$ which suggest that concerns about the provision of public services might contribute to explain people's fears and concerns about immigration (Hainmueller and Hiscox 2010).

As mentioned above, one possible response that avoids this fiscal burden on public services is increasing taxation of the rich. Nevertheless, governments with small welfare states or with low fiscal capacity might not necessarily raise taxes in response to more migration. In this context, the local population would have to compete with immigrants for the same social benefits. This is known as the "benefit adjustment model" (Meseguer and Kemmerling, 2018). Therefore, in places where people are more likely to rely on public services, anti-immigrant sentiments might rapidly grow among poor natives after an immigration shock.

The economic threat models predominantly focus on responses to voluntary migrants in North-South migration where migrants are mostly highly-skilled and where developed countries have a greater capacity to respond to the large-scale migration waves. Conversely, the benefit adjustment model can be better applied to the dynamics of South-South migration. The majority of refugees are hosted in

4. Hainmueller and Hiscox (2010) measure fiscal exposure using two indicators: state-level welfare spending and immigrant tax contributions. 
VEGA-MENDEZ AND VISCONTI

DOES IMMIGRATION INCREASE CONCERNS ABOUT THE PROVISION OF PUBLIC SERVICES?

EVIDENCE FROM COLOMBIA

non-developed countries neighboring their countries of origin, where migrants are mostly low-skilled and might need more support from the state, but from states that have little capacity to respond to the massive influx of economic migrants and refugees. Given developing states' limited capacity to increase tax revenues and the already deficient provision of public services to poor citizens, concerns about the provision of these services could increase in saliency after large demographic transformations.

In the case of Colombia after 2015, the country has received hundreds of thousands of people from Venezuela who were escaping from high levels of social, political, and economic insecurity, including a lack of access to basic goods and services such as medicine and food. A large number of the refugees and migrants from Venezuela are "families with children, pregnant women, elderly people and people with disabilities" (UNHCR, 2019). In response to this situation, the fiscal burden on public services model would predict that the host population might become increasingly concerned about the provision of public services.

Recent studies on public attitudes towards migrants in Latin America suggest that economic threats matter far more than cultural ones in shaping antiimmigrant sentiment. ${ }^{5}$ On average, anti-immigrant sentiment in Latin America is as high, or even higher than, in the US and Europe (Meseguer and Kemmerling, 2018). For instance, in the case of Costa Rican attitudes towards Nicaraguan migrants, Malone (2019) finds that when respondents perceive immigrants to be an economic threat, they are significantly more supportive of restrictive migration policies. $^{6}$

It is important to notice that immigration-related attitudes can also be explained by (mis)perceptions about the effects of demographic changes. For example, Severino and Visconti (2021) find that concerns about crime increased in Chile after a rise in immigration from Haiti, even though crime rates had not been affected by these demographic changes. ${ }^{7}$ This can be read as evidence of a disconnect between perceptions and the real consequences of migration. Similarly,

5. There is consistent evidence showing the importance of economic factors explaining people's preferences in Latin America (Murillo and Visconti 2017, Visconti 2019).

6. Another relevant factor for understanding support for transnational policies is trust in foreigners (Wals et al., 2015), which might have both economic and cultural dimensions.

7. Previous studies have shown that prejudice and discrimination against immigrants can increase based on how different they are from the native population (Brader, Valentino and Suhay, 2008). We have similar expectations for the case of Venezuelans in Colombia. Unfortunately, we do not have detailed data about immigrants' country of origin or race to make comparisons or explore for the heterogenous effects of immigration. In any case, we would expect that people who are more different from Colombians (acknowledging that Colombia was already a racially diverse country) might trigger more prejudice, which could contribute to an even greater increase in concerns about the provision of public goods. 
fear about the consequences of immigration may also be driven by a myopic focus on the short-term consequences of a demographic change. Evidence from the National Research Council shows that though the average immigrant to the US might impose a tax burden on natives in the short-term, they would become a net contributor in the long-run (Hainmueller and Hiscox, 2010). Nevertheless, because people have a hard time differencing between short- and long-term consequences (Healy and Malhotra, 2009; Achen and Bartels, 2016), we expect shortterm concerns to be driving their preferences and attitudes.

In this paper, we do not attempt to elucidate whether the increase in concerns about public goods is explained by a real or a perceived reason but rather to identify whether this worry exists. The existence of such concerns can become a relevant input for governments to try to address either the lack of provision or the misperception to then improve the integration of immigrants into their communities.

We hypothesize that given the contextual nature of the delivery of public goods in developing countries, people might become more concerned about education and healthcare in host countries, such as in Colombia after the 2015 economic and political crisis in Venezuela. To study the effects of migration, we follow a geographic proximity framework (Zhou, 2018), in which "mere exposure to the refugee crisis suffices to crystallize latent anti-immigrant attitudes and mobilize citizens to support exclusionary policies" (Hangartner et al., 2019, p. 446). We measure exposure using the distance from official borders between the two countries, as explained in the next section.

Hypothesis: We expect the concerns of Colombian citizens about healthcare and education after the 2015 immigration crisis to increase the closer they are to the Colombian-Venezuelan border.

\section{VENEZUELAN IMMIGRATION TO COLOMBIA}

Economic and political turmoil in Venezuela has induced the largest wave of regional migration in Latin American history. According to the United Nations High Commissioner for Refugees, Latin American countries host approximately 80 percent of the 5 million Venezuelan migrants (UNCHCR, 2019). By 2019, Colombia continues to be the largest recipient of refugees and migrants from Venezuela, reaching 1.4 million by August 2019 (UNCHR and OIM, 2019). Historically, Colombia has been a country with high levels of emigration due to its internal conflict, making Venezuela one of the main migratory destinations of Colombians. By 2016 Colombia had 7.3 million internally displaced persons (IDPs), the most in the world (Carvajal, 2017). In recent years, however, this trend has been reversed 
VEGA-MENDEZ AND VISCONTI

DOES IMMIGRATION INCREASE CONCERNS ABOUT THE PROVISION OF PUBLIC SERVICES?

EVIDENCE FROM COLOMBIA

due to the political and economic instability in Venezuela. This migration from Venezuela to Colombia takes place in the political context of Colombia's recent peace agreement with the FARC guerrilla group, a significant step towards ending half a century of internal conflict. Despite this, post-conflict Colombia faces several significant challenges: underdevelopment, inequality, and the concentration of means of production (World Bank, 2018).

There are more than 1.4 million Venezuelans in Colombia. This migratory influx is composed of economic migrants, returning population, and refugees; and it is balanced in terms of gender composition (Colombia Migration, 2018). Complex socioeconomic conditions characterize these migrants. The migrant population is two times more likely to be unemployed, and about half live in poverty. They also face an increasing lack of access to medical care. Similarly, irregular migrants have a level of non-attendance at school of about $40 \%$, which is more than twice the rate of the local population (World Bank, 2018; UNHCR and OIM 2019).

Local governments face greater challenges in providing social services for Venezuelan migrants in the border areas. For instance, there has been a significant increase in emergency medical care provided to the Venezuelan migrant population in government facilities. The resulting burden on health services, as in this example from North Santander, is considerable: "between January 2017 and the end of June 2018, emergency medical attention was provided to 19,108 Venezuelans in government health facilities in North Santander, and there were an additional 5,877 mobile clinic visits" (Doocy et al., 2019, p. 85). The Colombian education system is also experiencing significant challenges in response to these demographic changes. As of July 2018, the total enrollment of students born in Venezuela was 21,746 , more than double the number registered in the previous month (13,788 students) (Administrative Department of the Presidency of the Republic 2018, p. 50).

In general, the Colombian government has enacted a welcoming migration policy towards Venezuelan immigrants. Since 2017, the government passed new measures aiming to improve the management of the migrant population and promote access to basic services. The government developed two instruments to regularize migratory flow in border areas. First, "in November 2018, the Colombian government reopened registration for the Border Mobility Card (TMF, Tarjeta de Movilidad Fronteriza), which allows Venezuelans to enter Colombian border areas for up to seven days in order to obtain basic goods and services. Since then, more than 2.6 million Venezuelans have registered for the TMF" (R4V Response for Venezuelans, 2020). Second, to provide migrants with the opportunity to work and access healthcare, education, and financial services, the government created the permiso especial de permanencia (PEP). This permit provides access to emergency health care, employment, and education for migrants; and more than 600 thousand permits were issued through this response package (Colombia 
VEGA-MENDEZ AND VISCONTI

DOES IMMIGRATION INCREASE CONCERNS ABOUT THE PROVISION OF PUBLIC SERVICES?

EVIDENCE FROM COLOMBIA

Migration, 2019). Additionally, in March 2021 the government issued the Decree 216 implementing the Temporary Statute protection for Venezuelan migrants (Estatuto Temporal de Protección, ETP), which "allows the transit of Venezuelan migrants who are in the country from a temporary protection regime to an ordinary migratory regime" (Colombia Migration, 2021).

\section{RESEARCH DESIGN}

To assess how immigration can change citizens' perception of the provision of public goods, we use a difference-in-differences strategy (DID). The design is used to estimate the effect of a treatment by comparing the changes in outcomes over time. The canonical model analyzes two groups observed in two time periods. In the first period, none of the groups is exposed to the treatment condition; meanwhile, in the second period, one of them is exposed to the treatment condition (Wing et al., 2018). The design relies on the assumption that the outcomes in the treatment and the control group would follow the same trajectory in the absence of the treatment (Angrist and Pischke, 2008).

Our DID model uses a continuous instead of a binary indicator of exposure since we rely on distance from the border to measure the degree to which people are exposed to immigration from Venezuela. ${ }^{8}$ We compile data on the geographic locations of all of the official land border crossings between Colombia and Venezuela (i.e., latitude and longitude coordinates for each of them).

We use survey data from four rounds of the Latin American Public Opinion Project in Colombia from 2013 to 2018. We georeference each respondent's location by municipality using data from the National Administrative Department of Statistics in Colombia. By having geographic coordinates for each citizen respondent, then we calculate their proximity to each of the seven official border crossing sites between Colombia and Venezuela.

We construct a treatment indicator using the distance from the respondent municipality of residence to the nearest border crossing as an approximation of how exposed the respondent is to the large and rapid demographic transformation at the border. We understand the treatment as a measure of the intensity of exposure to immigration.

8. See Acemoglu, Autor, and Lyle (2004) for an example of using a difference-in-differences design with a continuous treatment. An alternative approach transforms the continuous treatment into a binary variable when implementing a canonical DID (e.g., Visconti, 2021). However, doing so would require a clear cutoff for the treatment variable, which is not the case when using distance from the border. 
Since we estimate the effect of exposure to the large and rapid immigration influx from Venezuela using distance to the closest border, we remove from our analysis respondents from the Colombia's largest cities, Barranquilla, Bogotá, Cali, and Medellín, since in those cases, the reception of migrants should not be explained by proximity to the border crossings. In appendix A, we implement the main analysis without excluding those municipalities, and the conclusions of the study are the same. Figure 1 illustrates all of the border crossings between Colombia and Venezuela. Five of them are land crossings and two are fluvial.

Figure 1. Border crossings between Colombia and Venezuela

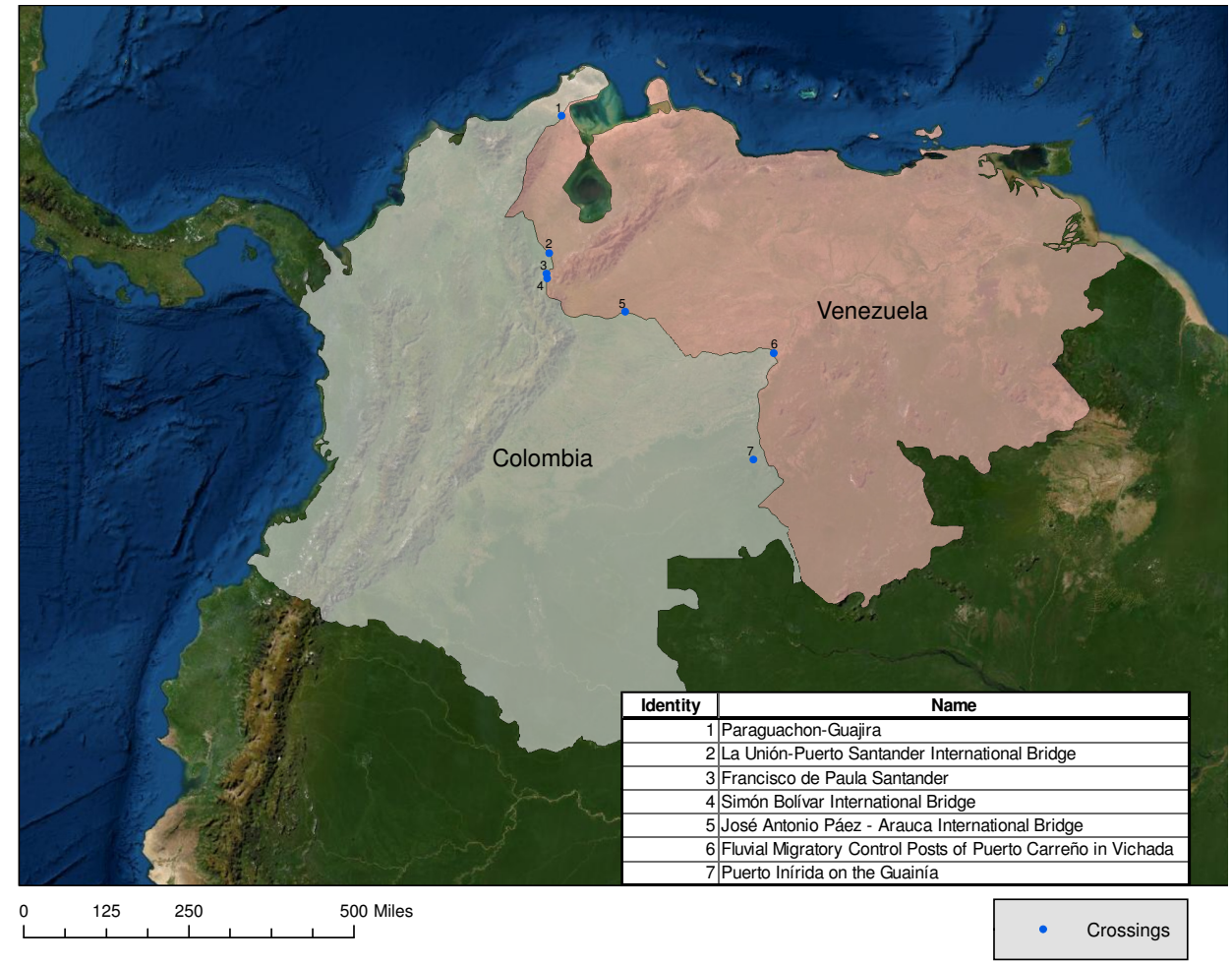

Source: own elaboration from DIAN (2021).

Migration to Colombia substantially changed in 2015, as humanitarian conditions worsened under Nicolás Maduro's regime. While 10,642 Venezuelans lived 
in Colombia in 2015, 769,726 resided there in 2018, as shown in figure $2 .{ }^{9}$ Following these dynamics, we use the 2013 and 2014 survey rounds for before and the 2016 and 2018 rounds for after the beginning of the 2015 immigration crisis. To give context to this distinction, in 2013 and 2014 12,357 Venezuelans entered Colombia (before the crisis) and in 2016 and 2018 that number increased to 809,037 (after the crisis).

Figure 2. Venezuelan Migrants in Colombia

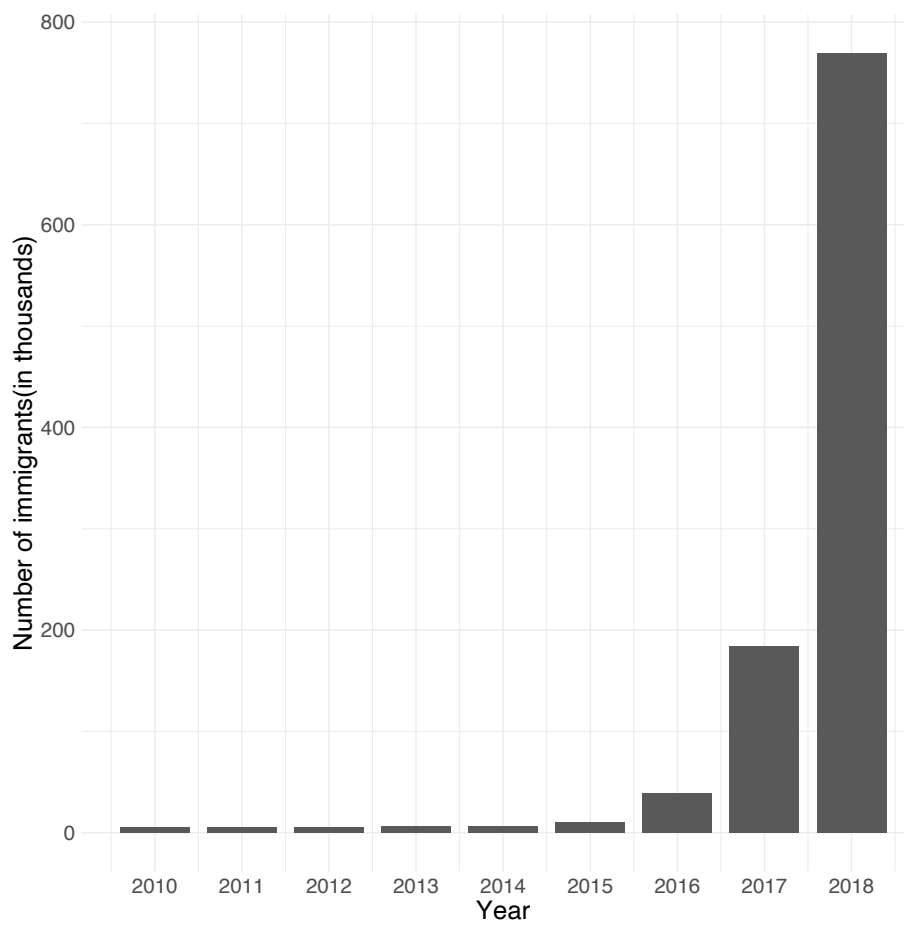

Source: own elaboration from Colombia Migration (2018, p.4).

The main outcome variables are constructed using the following question from the Latin American barometer: "In your opinion, what is the most serious problem the country is facing?" Respondents had to mention the issue they believed to be the most concerning. We generate binary indicators for whether respondents mentioned the following concerns related to the provision of public services as

9. Data from Colombia Migration (2018, p. 4). 
one of the most important issues: (lack of) healthcare and (lack of) education. ${ }^{10}$ We also use pretreatment and placebo covariates (i.e., individual characteristics that should not be affected by exposure to immigration). ${ }^{11}$ We use an OLS regression to estimate the effect of distance from border crossings after the influx of migrants from Venezuela.

$$
Y_{i t}=\alpha+\beta_{1} D_{i t}+\beta_{2} A_{i t}+\beta_{3} D_{i t} * A_{i t}+\beta_{4} X_{i t}+\epsilon_{i t}
$$

Y represents our outcome of interest, which is whether respondents consider a (lack of provision) of health or education as the most important issue Colombia is facing. $D$ is the measure of exposure to the immigration influx from Venezuela (i.e., distance to the closest border crossing). A refers to a binary indicator of whether the survey was conducted after the 2015 crisis in Venezuela. Our coefficient of interest is $\beta_{3}$, which corresponds to the effect of distance from the border after the 2015 crisis. $X$ corresponds to the set of placebo covariates. In appendix B we show that results are not conditional on including controls. Finally, we cluster the standard errors at the municipality level.

\section{RESULTS}

Table 1 provides the descriptive statistics of the variables used in the analysis. Five percent of respondents in our sample mention health or education as their main concerns. ${ }^{12}$ In addition, the average distance from the closest border crossing is $451 \mathrm{~km}$ and almost half of the sample participated in the surveys implemented before the 2015 crisis. Also, the average years of education is nine, the average age is 39 years old, and half of the sample is composed of female respondents.

10. Education: educación, falta de, mala calidad. Health: Salud, falta de servicio.

11. Education (in years), age (in years), gender (0: male, 1: female), size of the municipality (1: rural area, 2: small city, 3: medium city, 4: large city), deaths associated to violence between 2010 and 2012 at the municipality level (number of deaths).

12. While this number might seem low, it is important to notice that half of the sample are people who participated in the survey before the 2015 immigration crisis, and some of the respondents from post-2015 surveys live far from the border. As a result, the total concern about public goods is not as relevant as is how these concerns change based on the influx of people from Venezuela and the distance from the closest border. 
VEGA-MENDEZ AND VISCONTI

DOES IMMIGRATION INCREASE CONCERNS ABOUT THE PROVISION OF PUBLIC SERVICES?

EVIDENCE FROM COLOMBIA

Table 1. Descriptive statistics for main variables

\begin{tabular}{lccccc}
\hline & Mean & St. Dev. & Min & Max & N \\
\hline Concerns about (lack of) health care service & 0.03 & 0.18 & 0 & 1 & 4,193 \\
Concerns about (lack of) education & 0.02 & 0.13 & 0 & 1 & 4,193 \\
Distance to closest border crossing & 451.87 & 232.76 & 11.59 & 967.12 & 4,193 \\
After 2015 & 0.51 & 0.50 & 0 & 1 & 4,193 \\
Education & 9.09 & 4.14 & 0 & 18 & 4,193 \\
Age & 38.91 & 15.68 & 18 & 90 & 4,193 \\
Female & 0.50 & 0.50 & 0 & 1 & 4,193 \\
Size & 2.62 & 1.18 & 1 & 4 & 4,193 \\
$\begin{array}{l}\text { Deaths associated to political violence } \\
\text { (2010-2012) }\end{array}$ & 6.88 & 32.47 & 0 & 216 & 4,193 \\
\hline
\end{tabular}

Source: own elaboration from the AmericasBarometer (2013-2018) by the Latin American

Public Opinion Project (LAPOP), www.LapopSurveys.org, and CNMH (2010-2012).

Figure 3 reports the interaction ( $\beta 3$ ) coefficients and the $95 \%$ confidence intervals when using equation 1 , which refers to the effect of exposure to immigrants after the massive influx of people from Venezuela that started in 2015 (observations: 4,193). We present the results in percentage points to facilitate their interpretation. ${ }^{13}$ We also provide them in table format in appendix C. Concerns about the provision of healthcare significantly increase (decrease) by 0.01 percentage points for each kilometer respondents move closer to (away from) the nearest border crossing after the economic and political crisis in Venezuela ( $p$-value: 0.000). Simply put, when we reduce distance to the border, we increase concerns about health. This finding suggests that increasing exposure to immigration makes people care more about the provision of health services. As we expected, geographic proximity to Venezuela can trigger concerns about migration even in a context where these flows are temporary or transitory.

Regarding concerns about education, the immigration shock of 2015 has not had a substantive nor significant effect ( $p$-value: 0.701$).{ }^{14}$ We believe there might be two main explanations to understand this null finding. First, respondents

13. We multiply the results by 100 . Therefore, now we can directly interpret them as changes in percentage points without any transformation.

14. We implement different robustness checks and alternative analyses in D, E, and F. 
might be concerned about the provision of education but might not consider it the "principal problem the country is facing" when compared to other issues such as health. Second, in recent years Colombia has benefited from a demographic bonus. The 2018 Census showed an important reduction in fertility rates compared to previous years; as a result, the younger population is decreasing. ${ }^{15}$ In this context, Colombian schools have seen a reduction in enrollment year after year. ${ }^{16}$ For this reason, providing education to Venezuelans has not been as challenging, since schools are equipped to serve more children. The effects of the demographic bonus are different when it comes to health issues, where an aging population that is more affected by chronic illnesses leads to greater demand for health services.

Figure 3. Effects of distance to the closest border after 2015 on concerns about public goods provision

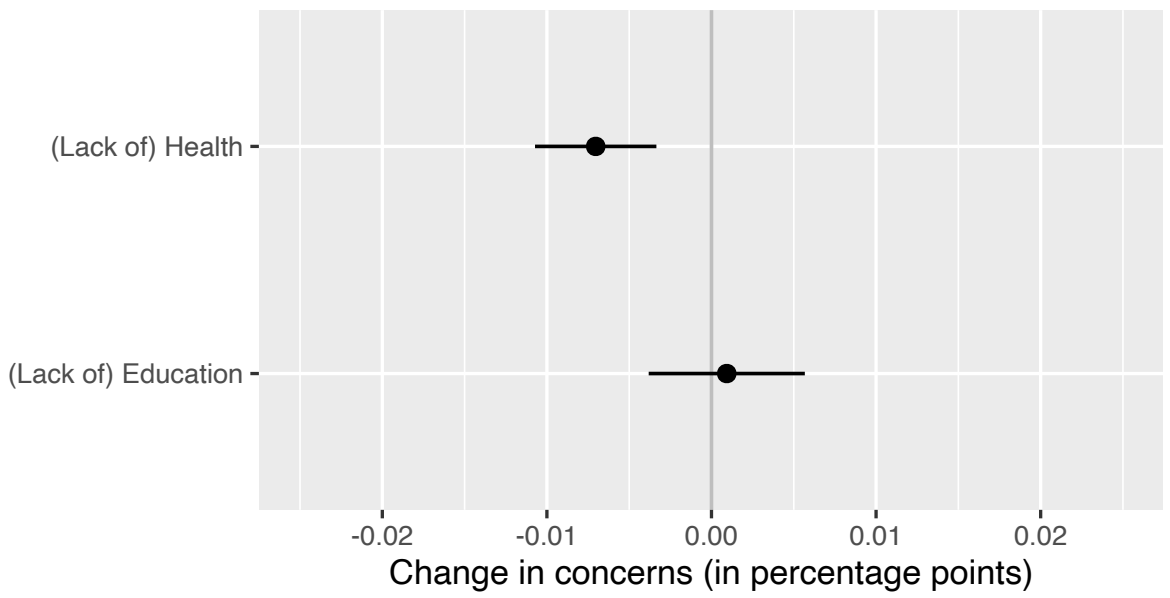

Source: own elaboration of AmericasBarometer (2013-2018) by the Latin American Public Opinion Project (LAPOP), www.LapopSurveys.org.

What explains the increase in concerns about health services? If we follow the "benefit adjustment model" (Meseguer and Kemmerling, 2018), governments with small welfare states might not raise taxes as a consequence of immigration and demographic changes. In this context, natives would have to compete with newcomers for the same amount of public goods and services. Following this

15. The birth rate in Colombia in 2018 was $14.88 \%$, and the Fertility index was 1.81 . In contrast, the birth rate in 2017 was $15.10 \%$ and the fertility index was 1.83 (DANE, 2018).

16. For instance, according to the 2018 Colombian Census "national enrollment was $9,916,546$ students, lower by $1.0 \%$ compared to 2017 enrollment (103,748 fewer students)" (DANE, 2018, p. 3). 
VEGA-MENDEZ AND VISCONTI

DOES IMMIGRATION INCREASE CONCERNS ABOUT THE PROVISION OF PUBLIC SERVICES?

EVIDENCE FROM COLOMBIA

argument, resource strain in border regions in a developing country such as Colombia, where a large part of the population depends on social services, can lead to a rise in concerns about the provision of healthcare. Host citizens living closer to bordering crossings might experience an increase in competition for social services as an additional economic threat to their well-being. Alternatively, it is possible that the increase in concerns about health services arises from potentially misplaced fears of competition or misperceptions of a deterioration in the provision of public services.

\section{CONCLUSIONS}

We use geocoded data of border crossing locations and survey data from Colombia to show how exposure to a large and rapid demographic change generated by a political and economic crisis in Venezuela can affect concerns about the provision of crucial public services such as healthcare and education. We find that exposure to the immigration wave from Venezuela affects concerns about health but not about education. These findings offer important insights into the consequences of migration in the Global South. The majority of forced and voluntary migration occurs in this region, but previous research tends to focus on how developed nations receive migrants from less privileged areas of the globe.

Immigration can stress states' social protection systems, especially in the Global South where countries are already struggling to offer social benefits for their citizens (Noy and Voorend, 2016). More specifically, demographic changes might produce tension when local communities perceive a deterioration in the provision of public goods. These perceptions could be explained by competition between locals and foreigners for scarce services or by prejudice and stereotypes about migrants rather than by real changes in the provision of public goods. In either case, these concerns about public services can contribute to anti-immigration attitudes, and as a consequence, affect the integration of refugees and economic migrants.

These findings have practical implications for humanitarian policymaking. Although the Colombian government has enforced a welcoming policy towards Venezuelan immigrants, it has not been able to meet their basic needs in border regions. These municipalities face a greater burden when hosting immigrants as they face significant gaps between demand for and their ability to provide basic social services. Therefore, in addition to strengthening institutional capacity to respond to immigrants' needs, immigration policies should advocate for the physical and social integration of immigrants into host communities. For example, as Otero-Bahamón (2020) shows, place-sensitive policies that take into account the local context help improve the provision of public goods. This type of 
VEGA-MENDEZ AND VISCONTI

DOES IMMIGRATION INCREASE CONCERNS ABOUT THE PROVISION OF PUBLIC SERVICES?

EVIDENCE FROM COLOMBIA

approach could soften concerns about the provision of public services in areas that that are experiencing significant challenges due to large and rapid demographic transformations.

\section{REFERENCES}

Acemoglu, D., D., H. Autor, and D., Lyle. (2004). Women, war, and wages: The effect of female labor supply on the wage structure at midcentury. Journal of political Economy, 112(3), 497-551. https://doi.org/10.1086/383100

Achen, C. H., \& Bartels, L. M. (2016). Democracy for Realists: Why Elections do not Produce Responsive Government. Princeton University Press.

Administrative Department of the Presidency of the Republic. (2018). Consejo Nacional de Political Economica y Social CONPES 115.

Alrababa'h, A., Dillon, A., Williamson, S., Hainmueller, J., Hangartner, D., \& Weinstein, J. (2021). Attitudes toward migrants in a highly impacted economy: evidence from the Syrian refugee crisis in Jordan. Comparative Political Studies, 54(1), 33-76. https://doi. org/10.1177/0010414020919910.

AmericasBarometer by the Latin American Public Opinion Project (LAPOP), www.LapopSurveys.org.

Angrist, J. D., \& Pischke, J. S. (2008). Mostly harmless econometrics: An empiricist's companion. Princeton University Press.

Borjas, G. J. (2001). Heaven's door: Immigration policy and the American economy. Princeton University Press.

Brader, T., Valentino, N. A., \& Suhay, E. (2008). What triggers public opposition to immigration? Anxiety, group cues, and immigration threat. American Journal of Political Science, 52(4), 959-978. https://doi.org/10.1111/j.1540-5907.2008.00353.x

Carvajal, D., (2017). As Colombia Emerges from Decades of War, Migration Challenges Mount | Migrationpolicy.Org.https://www.migrationpolicy.org/article/ colombia-emerges-decades-war-migration-challenges-mount

Castiglioni, R. (2001). The politics of retrenchment: the quandaries of social protection under military rule in Chile, 1973-1990. Latin American Politics and Society, 43(4), 37-66 http://dx.doi.org/10.1111/j.1548-2456.2001.tb00187.x

Colombia Migration. (2018). Todo lo que tiene que saber sobre la migración venezolana Migración Colombia. https://www.migracioncolombia.gov.co/infografias/229-infografias-2019/todo-lo-que-tiene-que-saber-sobre-la-migracion-venezolana

Colombia Migration (2019). ESPECIAL - Así ha sido la evolución de la crisis migratoria venezolana -corte agosto 31 de 2019 - Migración Colombia. https://migracioncolombia. gov.co/infografias/231-infografias-2019/especial-asi-ha-sido-la-evolucion-de-la-crisis-migratoria-venezolana-corte-agosto-31-de-2019).

Colombia Migration (2021). ABECÉ Estatuto temporal de protección para migrantes venezolanos -Migración Colombia. https://www.cancilleria.gov.co/sites/default/files/FOTOS2020/ok._esp-_abc_estatuto_al_migrante_venezolano-_05mar-2021.pdf 
VEGA-MENDEZ AND VISCONTI

DOES IMMIGRATION INCREASE CONCERNS ABOUT THE PROVISION OF PUBLIC SERVICES?

EVIDENCE FROM COLOMBIA

CNMH. (2010-2012). Bases de datos - ¡Basta ya! Colombia: Memorias de guerra y dignidad. http://www.centrodememoriahistorica.gov.co/micrositios/informeGeneral/basesDatos.html

Dancygier, R. M., \& Laitin, D. D. (2014). Immigration into Europe: Economic Discrimination, Violence, and Public Policy. Annual Review of Political Science, 17(1), 43-64. https://doi. org/10.1146/annurev-polisci-082012-115925

DANE. (2018). Boletín técnico Educación formal (EDUC) 2018. 34. https://www.dane.gov. co/files/investigaciones/boletines/educacion/bol_EDUC_18.pdf

DANE. (2018). Estadísticas Vitales (EEVV). 23.

DIAN. (2021). Pasos de Frontera - DIAN. https://www.dian.gov.co/aduanas/Paginas/Pasos-de-Frontera.aspx.

Doocy, S., Page, K. R., de la Hoz, F., Spiegel, P., \& Beyrer, C. (2019). Venezuelan Migration and the Border Health Crisis in Colombia and Brazil. Journal on Migration and Human Security, 7(3), 79-91. https://doi.org/10.1177/2331502419860138

Economic Commission for Latin America and the Caribbean. (2016). ECLAC Analyzes Social Protection and Access to Public Goods and Services in Colombia's Rural Areas. https:// www.cepal.org/en/news/eclac-analyzes-social-protection-and-access-public-goodsand-services-colombias-rural-areas.

Facchini, G., \& Mayda, A. M. (2009). Does the welfare state affect individual attitudes toward immigrants? evidence across countries. The Review of Economics and Statistics, 91(2), 295-314. https://doi.org/10.1162/rest.91.2.295

Garay, M., C., (2010). Including Outsiders: Social Policy Expansion in Latin America. UC Berkeley. https://escholarship.org/uc/item/6dd0h7j3

Giraudy, A., and J., Pribble. (2020). Territorial Inequality in Health Service Delivery: Lessons from Latin America's Federations. Latin American Politics and Society 62(3), 19-43. https://doi.org/10.1017/lap.2020.5

Hainmueller, J., \& Hiscox, M. J. (2010). Attitudes toward Highly Skilled and Low-skilled Immigration: Evidence from a Survey Experiment. American Political Science Review, 104(1), 61-84.

Hainmueller, J., \& Hopkins, D. J. (2014). Public Attitudes Toward Immigration. Annual Review of Political Science, 17(1), 225-249. https://doi.org/10.1017/S0003055410000389

Haggard, S., \& Kaufman, R. R. (2008). Development, democracy, and welfare states: Latin America, East Asia, and eastern Europe. Princeton University Press. http://dx.doi. org/10.1111/j.1468-0491.2009.01472_2.x

Hangartner, D., Dinas, E., Marbach, M., Matakos, K., \& Xefteris, D. (2019). Does Exposure to the Refugee Crisis Make Natives More Hostile? American Political Science Review, 113(2), 442-455. https://doi.org/10.1017/S0003055418000813

Hanson, G. H., Scheve, K., \& Slaughter, M. J. (2007). Public Finance and Individual Preferences Over Globalization Strategies. Economics \& Politics, 19(1), 1-33. https://doi. org/10.1111/j.1468-0343.2007.00300.x

Healy, A., \& Malhotra, N. (2009). Myopic voters and natural disaster policy. American Political Science Review, 387-406. https://doi.org/10.1017/S0003055409990104

Huber, E., Mustillo, T., \& Stephens, J. D. (2008). Politics and Social Spending in Latin America. The Journal of Politics, 70(2), 420-436. https://doi.org/10.1017/S0022381608080407 
VEGA-MENDEZ AND VISCONTI

DOES IMMIGRATION INCREASE CONCERNS ABOUT THE PROVISION OF PUBLIC SERVICES?

EVIDENCE FROM COLOMBIA

Huber, E., \& Stephens, J. D. (2012). Democracy and the Left: Social Policy and Inequality in Latin America. University of Chicago Press. http://dx.doi.org/10.4067/ S0718-090X2013000200007

Malone, M. F. T. (2019). Fearing the "Nicas": Perceptions of Immigrants and Policy Choices in Costa Rica. Latin American Politics and Society, 61(1), 1-28. https://doi.org/10.1080/ 10439463.2020.1744600

Meseguer, C., \& Kemmerling, A. (2018). What Do You Fear? Anti-immigrant Sentiment in Latin America. International Migration Review, 52(1), 236-272. https://doi. org/10.1111\%2Fimre.12269

Murillo, M. V., \& Visconti, G. (2017). Economic performance and incumbents' support in Latin America. Electoral Studies, 45, 180-190. https://doi.org/10.1016/J. ELECTSTUD.2016.10.007

Niedzwiecki, S., (2016). Social Policies, Attribution of Responsibility, and Political Alignments: A Subnational Analysis of Argentina and Brazil. Comparative Political Studies 49(4), 457-98. https://doi.org/10.1177/0010414015612392

Noy, S., \& Voorend, K. (2016). Social rights and migrant realities: Migration policy reform and migrants' access to health care in Costa Rica, Argentina, and Chile. Journal of International Migration and Integration, 17(2), 605-629. http://dx.doi.org/10.1007/ s12134-015-0416-2

Otero-Bahamón, S. (2020). Place-Sensitive Policies in the Provision of Subnational Public Goods in Colombia. Latin American Politics and Society, 62(3), 94-122. https://doi. org/10.1017/lap.2020.8

Pribble, J. (2011). Worlds apart: Social policy regimes in Latin America. Studies in Comparative International Development, 46(2), 191-216. https://doi.org/10.1007/ s12116-010-9076-6

Pribble, J., (2015). The Politics of Building Municipal Institutional Effectiveness in Chile. Latin American Politics and Society 57(3), 100-121. https://doi. org/10.1111/j.1548-2456.2015.00276.x

R4V Response for Venezuelans. (2020). Refugee and Migrant Response Plan. https://reliefweb.int/sites/reliefweb.int/files/resources/73277.pdf

Rodríguez Takeuchi, L. K. (2009). Los municipios colombianos y el conflicto armado. Una mirada a los efectos sobre la efectividad en el desempeño de los gobiernos locales. Colombia Internacional, 70, 93-120. https://doi.org/10.7440/colombiaint70.2009.04

Samuelson, P. A. (1954). The pure theory of public expenditure. The review of economics and statistics, 387-389. https://doi.org/10.2307/1925895

Scheve, K. F., \& Slaughter, M. J. (2001). Labor market competition and individual preferences over immigration policy. Review of Economics and Statistics, 83(1), 133-145.

Segura-Ubiergo, A. (2007). The Political Economy of the Welfare State in Latin America: Globalization, Democracy, and Development. Cambridge University Press. https://doi. org/10.1017/CBO9780511510984

Severino, F., and G., Visconti. (2021). Immigration Shocks and (Mis)Concerns about Crime: Evidence from Chile. Working paper, Purdue University.

Simon, J. L., Ungar, S. J., \& Moore, S. (1999). The Economic Consequences of Immigration. University of Michigan Press. 
Tilak, J. B. (2008). Higher education: a public good or a commodity for trade? Prospects, 38(4), 449-466. DOI 10.1007/s11125-009-9093-2

UNHCR. (2017). UNHCR Global Trends - Forced Displacement in 2017. UNHCR Global Trends - Forced displacement in 2017.

UNHCR. (2019). Document - UNHCR Venezuela Situation: Supplementary Appeal - January - December 2018 [EN]. https://data2.unhcr.org/en/documents/details/63088

UNHCR, and OIM. (2019). Regional Refugee and Migrant Response Plan for Refugees and Migrants from Venezuela (January - December 2020). Regional Inter-agency Coordination Platform: 180.

Visconti, G. (2019). Economic Perceptions and Electoral Choices: A Design-Based Approach. Political Science Research and Methods, 7(4), 795-813. https://doi.org/10.1017/ psrm.2017.26

Visconti, G. (2021). "Do disasters affect policy priorities? Evidence from the 2010 Chilean earthquake." Journal of Elections, Public Opinion, and Parties.

Wals, S. C., Theiss-Morse, E., Gonzalez, F. J., \& Gosda, T. (2015). Love thy neighbor? Trust in foreigners and support for transnational policies. Political Research Quarterly, 68(3), 537-551 https://doi.org/10.1177\%2F1065912915594253

Wing, C., Simon, K., \& Bello-Gomez, R. A. (2018). Designing Difference in Difference Studies: Best Practices for Public Health Policy Research. Annual Review of Public Health, 39(1), 453-469. https://doi.org/10.1146/annurev-publhealth-040617-013507

World Bank. (2018). Migración desde Venezuela a Colombia: impactos y estrategia de respuesta en el corto y mediano plazo. World Bank.

Zhou, Y.-Y. (2018). Refugee Proximity and Support for Citizenship Exclusion in Africa. Available at SSRN: https://ssrn.com/abstract=2454409 


\section{APPENDIX}

\section{Appendix A: Results with all municipalities}

Figure A1 reports the main analysis but without excluding Colombia's largest cities, Barranquilla, Bogotá, Cali, and Medellín (observations: 6,174). The conclusions of the study are the same regardless of excluding or keeping these municipalities in the sample.

Figure A1. Effects of distance to the closest border after 2015 on concerns about public goods provision (all municipalities)

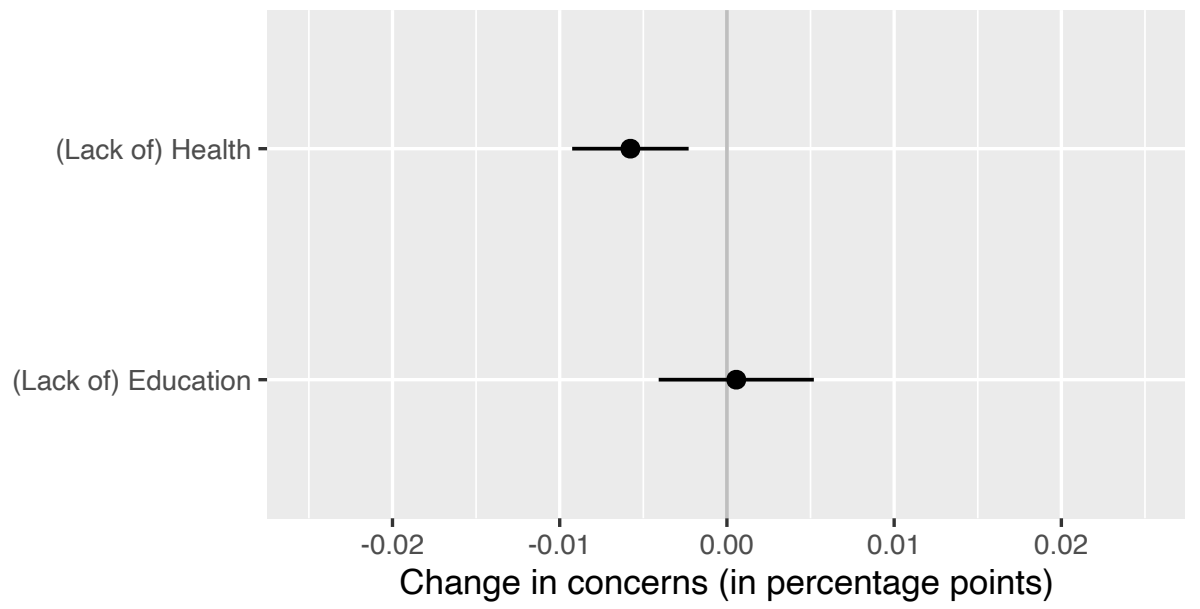

Source: own elaboration from LAPOP (2013-2018).

\section{Appendix B: Results without controls}

Figure A2 reports the main results without using controls (education, age, gender, size of municipality, and deaths associated to political violence). The conclusions of the study are the same regardless of including controls or not. 
Figure A2: Effects of distance to the closest border after 2015 on concerns about public goods provision (no controls)

(Lack of) Education -

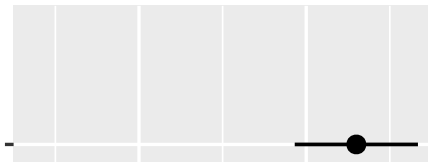

(Lack of) Health -

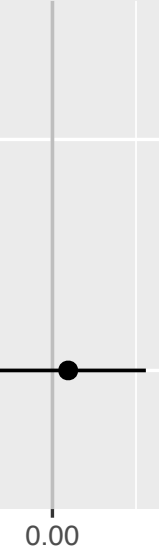

0.01

0.02

$-0.02$

$-0.01$

0.00

ints)

Source: own elaboration from LAPOP (2013-2018).

Appendix C: Regression results in table format

Table A1 presents the results from figure 3 in table format.

Table A1. Difference-in-differences

\begin{tabular}{lcc}
\hline & Lack of health & Lack of education \\
\hline Distance to the closest & $-0.01^{* * *}$ & 0.00 \\
border*After 2015 $(\beta 3)$ & $(0.00)$ & $(0.00)$ \\
Observations & 4,139 & 4,139 \\
Placebo covariates & Yes & Yes \\
\hline
\end{tabular}

Note: ${ }^{*} \mathrm{p}<0.1 ;{ }^{* *} \mathrm{p}<0.05 ;{ }^{* * *} \mathrm{p}<0.01$. Variables not shown: distance to the closest border $\left(\overline{\beta_{1}}\right)$, after $2015\left(\overline{\beta_{2}}\right)$, and placebo covariates $\left(\overline{\beta_{4}}\right)$.

Source: own elaboration from LAPOP (2013-2018). 


\section{Appendix D: Perceptions about Venezuela}

The LAPOP survey included one question about Venezuela in their 2014 round (before the influx of immigration). As a result, we check whether distance to the border is a predictor of perceptions about Venezuela (using the same controls included in equation 1). Though the question asks about Venezuela being a model of development and not about perceptions of Venezuelans, this is the best proxy we found to try to address this concern. The results in table A4 show that distance to the border is not a relevant predictor of perceptions about Venezuela.

Table A2. Distance to the border and perceptions about Venezuela

\begin{tabular}{lc}
\hline & $\begin{array}{c}\text { Perceptions about } \\
\text { Venezuela }\end{array}$ \\
\hline Distance to the closest border & -0.003 \\
Observations & $(0.002)$ \\
Placebo covariates & 1,493 \\
\hline
\end{tabular}

Note: ${ }^{*} \mathrm{p}<0.1 ;{ }^{* *} \mathrm{p}<0.05 ;{ }^{* * *} \mathrm{p}<0.01$. Variables not shown: placebo covariates. Source: own elaboration from LAPOP (2013-2018).

\section{Appendix E: Road distances}

As a robustness check, rather than a distance computed using latitude and longitude, we use road distances between borders and municipalities. The main conclusions of the study are the same regardless of the approach used to compute distances. 
Figure A3. Effects of distance to the closest border after 2015 on concerns about public goods provision (road distance)

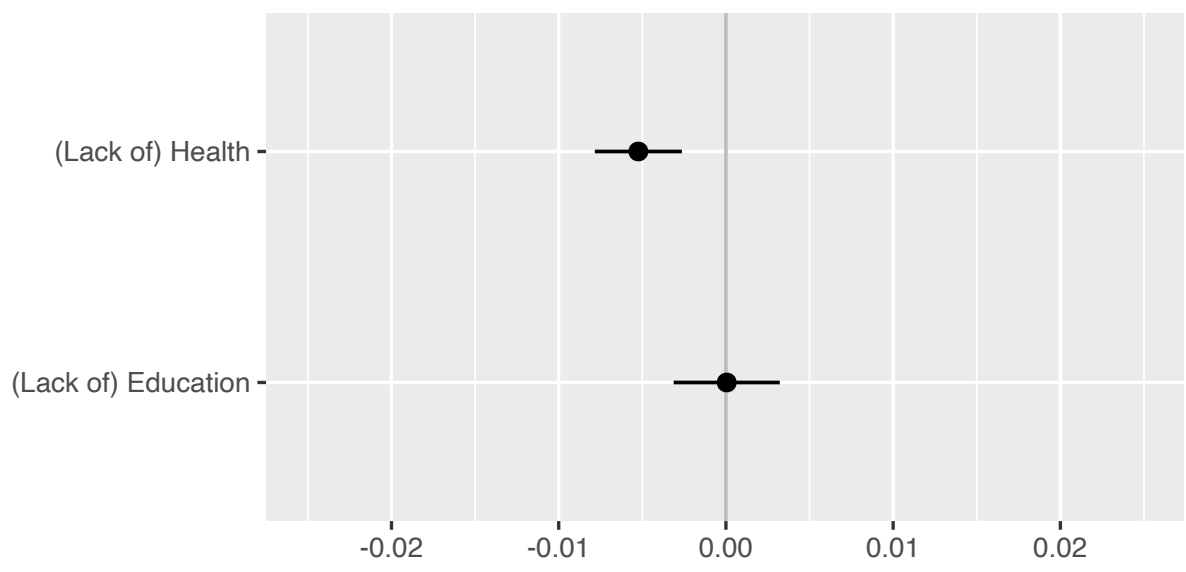

Source: own elaboration from LAPOP (2013-2018) and Google Maps.

\section{Appendix F: Income}

In this section, we use income as an extra control and check for heterogeneous treatment effects based on income. Figure A4 provides the main findings using this new covariate in the regression analysis. The conclusions of the study are not changing. 
Figure A4. Effects of distance to the closest border after 2015 on concerns about public goods provision (including income as a covariate)

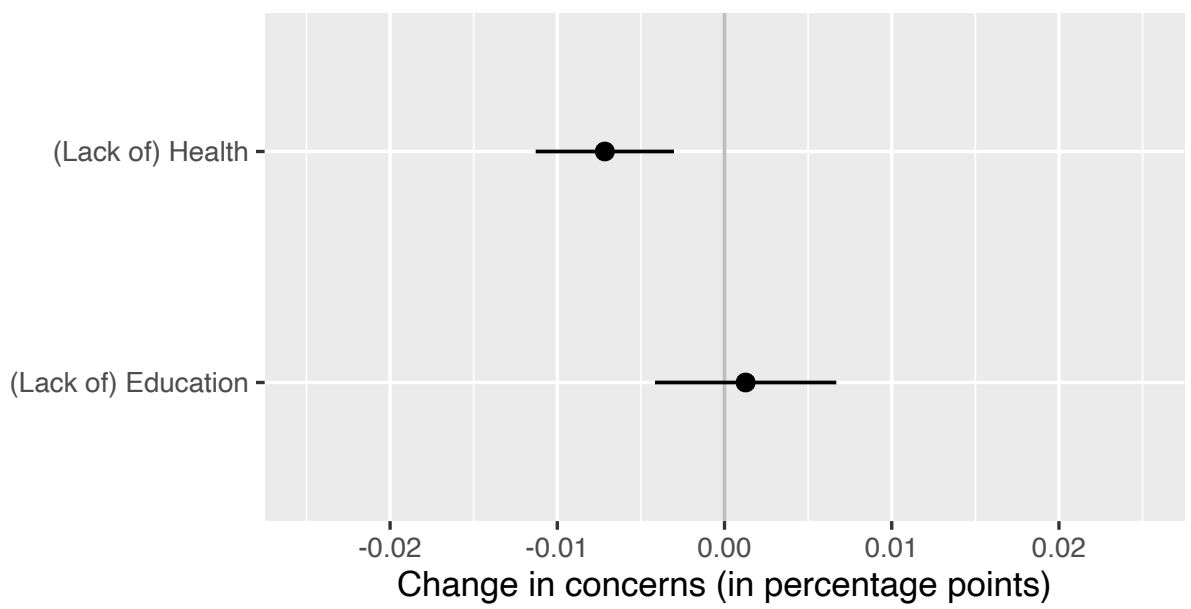

Source: own elaboration from LAPOP (2013-2018).

We also explore heterogeneous treatment effects by interacting income with distance and after 2015 (and including all the other respective interactions to correctly specify the equation). We do not find evidence to claim that lower-income people might be reacting differently than higher-income citizens.

Table A3. Heterogenous effects by income

\begin{tabular}{lcc}
\hline & Lack of health & Lack of education \\
\hline Distance to the closest & -0.0003 & -0.0003 \\
border*After $2015^{*}$ Income & $(0.0004)$ & $(0.0003)$ \\
Observations & 3,491 & 3,491 \\
Placebo covariates & Yes & Yes
\end{tabular}

Note: ${ }^{*} p<0.1 ;{ }^{* *} p<0.05 ;{ }^{* * *} p<0.01$. Variables not shown: distance to the closest border, after 2015, and placebo covariates.

Source: own elaboration from LAPOP (2013-2018).

However, one of the issues with using income is the high number of missing values and that some covariates such as age and gender are highly predictive of missingness. 
